
stroom

\title{
REGIONAL AND CURRENT PROBLEMS IN SOUTH AFRICA AND THEIR IMPACT ON LITERATURE WITH REMARKS ON THE EVALUATION OF THE AFRI- KAANS NOVEL*
}

\section{INTRODUCTION}

My paper centres round a specific situation and its impact on literature in South Africa with special reference to the moklern novel in the Alrikaans language and the literary evaluation of the novel. This does not mean that I exclude references to the other genres, poetry and drama and to literatures in other languages within the South African context. Many of you might know but to clarify I would like to point out that I refer to Afrikaans as the Germanic language originating from the 17th century Dutch mother tongue of approximately $3 \frac{1}{2}$ million South Africans.

\section{LITERATURE}

I use the term literature to refer specilically in this context to litcrary literature - literature which belongs to the so-called "belles lettres" and which has won respect in the eyes of the literary crit ics. Categories of literary value are, to my mind, universality, ambiguity, originality, imagination -much heard-of merits of the literary phenomenon. Literary value and literary evaluation are very complex issues. Suflice it to mention the more important categories of value.

\section{LITERATURE IN SOUTH AFRICA}

It is obvious that in South Africa, as in many other countries, a delinite actual and political situation has an ellect on its literature. National circumstances are closely related to the development of the so-called "litcerature engagée". This fact has been conlirmed time and again by lectures already given at this congress. Again I must state that of course all literature is in one or other way engaged, especially when it centres around

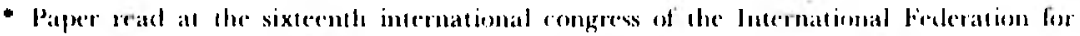
medern languages and liectature, 22-27 August I984 in Budapest, Howgary. 
universal human emotions like love, sorrow and the experience of beauty. In this respect literary arlis/s are all alike, also those who refer to and include the South African "scene" in their writings :

'a poet is the same, the same breed continuous to love, beanty and hate oppression, to believe in spiritual values and the mind's allinities ...' (Macl)iarmid, 1974:15).

South $\Lambda$ frica has a variety of literatures which correlate with the varicty of language groups within its borders: Twelve peoples and nine languages apart from the Afrikaans and English language cultures. Afrikaans litcrature and English literature are created by authors from diflerent ancestries. Not only the true linglish-speaking person in South Africa but people from all creeds in South Africa write in Engl ish. In this respect there is an cudeavour to reach the widest possible audience for commercial and idcological reasons, also because it is the language (the lingua franca) many people are taught in.

With so many literatures, oral and written, one would think that those literatures created within a relative geographic and constitutional unity should excercise a considerable influence on one another. This is actually not the case, when one looks at parallel themes or motifs. One subject, though, which towers above all ot hers is the subject of human relations. Before I elaborate on this I would like to point out that one could in a way utilize the polysystem theory of 1. Even-Zohar (1979:288) by which one could dist inguish several divisions within the South $\Lambda$ frican context dominated and organized by a particular national situation. One could dist ingu ish several calegories.

Fvery one of thesc following categories has its own peculiarities :

3. I The Afrikaans-language literature mainly created by White authors though not all of them white because coloured people are writing in English as well. The $\Lambda$ frikaans novel belongs to this system.

3.2 'The English-language literature, mainly created by White authors which of course ties in with the mainstream of English literature (English and American).

3.3 The linglish litcrature, mainly written by Black authors strongly connected with the South Nerican English literature mentioned in 4.2. voluntarily (Rive, R. 1977:14). 
3.4 Litcrature, written or oral, by Black authors in the 9 other main languages of South Alrica.

Dissatisfaction with the social order forns a common theme in the literatures mentioned above, especially after 1960 , with one barticr between these systems - that being a language barrier. In connection with the common theme of dissatislaction with the social order in South Africa a Time columnist referred with envy to Nadine Gordimer who has such a rich source to choose her subjects from :

"South Africa ... that outlaw nation on a seething, exotic cont incent, with a social system based on a fiction of magnilicent lolly' (Rapport, 22/07/84).

Though this view is somewhat exaggerated, one can say that many present novelists in South Africa are, as a result of the current situation in that part of the continent of Africa, "leing challenged to confront a society in tension" (South difram Outlook, Vol. 114, no. 1355).

\section{SOUTH AFRICAN LITERATURE}

Firstly I would like - very briedly - to refer to the

\subsection{South African English Literature}

One could, as alrearly mentoned, in this respect distinguish between two units: linglish literature written by White authors and tinglish literature written by Black authors. A good example of the first category is Allan Paton's lamous novel (in the beloved country (1948), translated into many languages and Natline (Sordimer's Burger's dangher (1979). I would like to claborate briefly on the second category which, ironically, is partly unknown to many people in South Africa and better known by people: alroad. 'I'his relates particularly to the literature of the sixties which was subjected to censorship with the result that many books were banned. Alier the Sharpeville ureising many authors who identilied themselves with the anti-apartheid movements were forced to leave the country, or did so voluntarily (Rive, R. 1977:14).

'This situation has changed. In an interview Richard Rive, head of the department of English of the Hewit 'Training College Athlone, Catpe Towu, points out that Black lit erat ure nowadays flour ishes, due to the emergence of magatinc's like, Ytaffrider and The newe classic. 
Thematically a change or a kind of development occurred during the liftirs and up to the cight ies. At lirst the school of protest poctry or prose (especially short prose) existed, writıen in English with the idca of having the Whites read it. In the late seventics and eight ies the Black art ist rather writes about Black identity and Black consciousness, works for the Blacks about the Blacks in order to ascertain their place in the world. These are rather variants of the protest poctry of the fift ies, but protest poetry with a much greater impact.

This kind of protest literature has been encouraged, inter alia, from inside as well as from outside the country (USA). As an example one can mention the poct Malika Pascal Gwala in his pocm "On being human"

'One thought never leaves

That one is human

with feclings of love and hate

with pangs of desertion and embrace

with imer urge to destroy and create'.

Many of his poems show bitterness against Black people who think of themselves in terms of their being "non-Europeans" and not as people in their own right with their own identity and pride.

He has eloguently pleaded that literature must not only be bound to its own period, but that it should be exalted above its own period and should refer more specitirally in the universal existence of mankind.

In this regard Audre $P$. Brink states in the introduction to a book of poems entitled $A$ unotd of their ouen (1976) that the literature of the Fifties and Sixties "was overtly and sometimes movingly involved in the "South African experience', mainly with socio-political overtones sustained by all the anger and lierce inspirat ion of litlerature engagée, but often limited hy the inhibitions and superficialities and frustrations of a content and a context too narrowly identified with a local habitation and a name".

\subsection{THE AFRIKAANS NOVEL FROM THE BEGINNING}

Regarding the Afrikaans novel, on which I will concentrate, one must look al the historical social siluation of the Afrikaans people, commonly known as descendants of the Boers, well-known to Europe because of their fierce and heroic struggle during the destructive Anglo-Boer War which lasted for lhree years (from 1899-1901). Because of their scorched-earth policy, the British army destroyed farms, cattle were killed or taken and women and children were herded into concentration camps. Those Bocers who escaped 
death on llec battle-lield returned to their larms penniless and hatd to make a living from scrateh. The Boer War thus created, at that lime, one of the greatest social problems in South dirica, the so-called poor Whites problem. 'I his problem was later on aggravated by the Wall Street Collayse and the succeceding world recession.

From this many related literary themes enanated: One of these was the social problem of urbanizat ion. This theme included some permanent vicws of the Afrikaner, e.g. his traditional rural and religious ties. If one takes the prestigious Hertzog Literary Prize as a standard of literary evaluation for nearly 40 years from its inception in 1915 to the early sixties, these themes pervasively ligured in the prize-winning novels. To some extent litcrary criticism and literary evaluat ion ran concurrently with a social sit uation, not uncommon in the "prize-winning business" - the Nobel Prize awards are, I think, often made along the same lines.

Another chatacteristic of the Afrikaans-speaking people was its strong religious sentiments. This too is manifested in literature, as secn in the works of a Hertzog Prize winner, a professor in Afrikaans literalure, 1).F. Malherbe, for his books on Biblical themes (1939), books which made an appreal to the religious sentiments of the Alitikans readers but according to literary nor ins never reached a high standard. 'Today those novels are simply historical documents.

Afrikaans literature in South Africa before Worle War II, from the point of view of the implicit author, with some exceptions, "never" revealed racial tension in its intrigue and characters. This conclusion dilfers from readen to reader, especially when the reader is a coloured or a black reader. Jakes Gerwel (professor of Afrikatans at the University of the Western (aape) has a reading experience or reception of these books which shows, for instance, an explicit rlissat isfaction with the representation of coloured people: He statcs that in the works referred to there is a constant representation of the coloureds as a diflerentiated social category characterised by almormal social behaviour patterns, a comical and pathetic deliciency in the espression of imitated cultural patterns, emotional bankruptcy or childishness and in general a fall from the completeness of being a human being. This may be the case, but racial themes were not at all intencled to be peripheral, rather than accentuated in these novels.

Though South Alrica took part in the hostilities, World War II dicl not have a greal cllect on Afrikaans litcralure as such. ho 1942, during the war, the Ilertzog Prize wass awarded to C..M. van den Ifever lor his book entitled last unugle (late/ruit) a novel about the etcrmal cycle of youth, adult life, age; 
about a dictator larmer whose life is in the end fulfilled by his son and his son's children.

\subsubsection{The great explosion}

The great explosion in the Afrikaans literature and its appreciation came about during the sixties, concurrently with the advent of the Republic of South $\Lambda$ frica. This meant to a large part of white South $\Lambda$ fricans (more than $60 \%$ of that group) the emancipation from Great Britain and the restoration of a republic, reminiscent of the old Boer Republics of the turn of the century. This in turn had a profound effect on the nature of the Afrikaans novel and the st andard of literary evaluation. No longer were novels used to describe the $\Lambda$ frikaans people in their very limited social and religious and economical conflicts, but their social surroundings in a wider community of people's context came to be protrayed. This resulted in a fierec struggle of conllicting values.

The lirst object of this struggle: was a novel, published in 1962 just after the Sharpeville uprising, cntitled Sewe dae by die Silbersteins (Seven days at the Silbersteins), written by Ftienne Leroux, of which Jack (Cope (1983: 116) states:

"Ihis book was published soon after Sharpeville and contains a resonance from that time of crisis and insecurity. It made a furore in literary circles and was se'n as a great advance in Alrikaans liction".

lt brought about a complete change in the literary scene in South Africa. One may label this as an era of social realism in South Alrican literary history. One would guess that this system might be part of a greater South Arican polysystem (op. cit.) and might even form the contre of it. Ihis is especially the case with its contcnt but not is form. Regarding form, the Afrikaans novel of the sixtics actually in a way belongs to a Western European polysystem wilh its centre in France, inspired by Robbe-Crillel, Sartre, (amus. This is due to the fact that many of the Afrikaans avantgarde authors lived and worked and studied in France, familiarizing themselves with the avant-garde literature of that country.

The following trends manifest themselves within the system to which the Afrikaans novel belongs :

a. 'There is dissatisfaction with a social order.

b. 'The "outsider" becomes quite prominent (i.e. litienne leroux's tien vir 
lzasel (One for the devil).

c. Religion as a theme disappears from the literary scene and is often used in a negative way much to the anger of many "unliterary" Afrikaans language reaulers. Other religions manifest thentsetves. It is Breycen Breylenbath who for instance introduced Len Budelhism to Alrikatus literature with the publication of hatastofes in 1964 (catastiophes) and many othe' of his poems.

d. Authors within this system stant toexperiment with several tools from the litcrary loolkit, for instance with point of view. Fantasy and surrealism become an important part of the literary system. Ihis applies especially to André Brink who from the beginning experimented with his novel dobola ter die lecee (Pledge for life) of 1962. A climax of experiment within the system of the Alrikadas language is his most recent look /loml-den-beh (1983), with its inclictment of the establishment by using a historical vicwpoin picturing rural life with Afrikaans-speaking larmers with their non-white servants and slaves. Every character receives a turn - in a changing dialogue - to air his view on certain events. The accent is on Black-White relations. Within the scope of the Alrikans literature language this brings about a new techuicfuce - in a wider context however, this is not new. Louis Panl Boon (M/cmet) and Hugo Cilaus (be Metsiers) used this technigue derived from William raulkner.

e. Ifigures of speech like irony combined wilh salire, are used mone extensively. It is again Elienne l croux who lits in perlectly in this aspect of the system with his novel Magers/ontein, o Magersfontein! One detects a kind ol sadist ic satire in which the "story" ol a heroic Boer battle and victory is transformed into an indiclnent of the present establishment.

f. The new trends bring about a correlative shift in literary erit icism. Panels of judges of the Hertzog Prize have come up to date with the new literary scence. I'wo years atier the publication of Seven taj's wilh the Silbersteins they

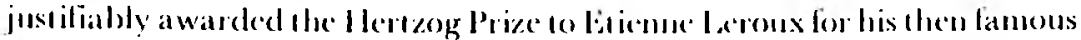
novel. This caused a public outcry - suddenly "literary evaluation" became public: popenty. Some people branded the novel as a (ommmost plot, not recognizing the very noble appeal of the novel, contained in a renalk by thenry, one of the main character's who says :

"llee lault lies with us Whites. We must learn to gee rid ol'our old lixed icleas. We must seareh our own hearts. We must learn to think courageously'.

Aubers like Brink, I ceroux and Elsat Joubert (Poppie. Vongena) and others 
appear to lave a strong vocation to deal with - and this is molerstandable - the bocal scene. 'This intensive engagement with the local scene may have the result that these novels do not attain a fourth elimension and clo not become monersal manifestat ions ol men in dislress, which an be discomeceted trom the Somb Mirican secue. "The publications of these novels ofien become "happenings" on the lilerary front. The present situation in Sonth Arica evokes the creation of political movels which prevent the coreation ol movels with a great porential for monersality, although not intensely engaged with the social problents of South $\Lambda$ rica.

Another clfect is that the focus of literary criticism of prose in South Africa is forced in the direction of the novels thus engaged. 'This also happens because: these novels are translated into many languages and world opinion is focussed on them not necessarily because of iheir literary value.

(I confine myself to the $A$ rikatus novel, which neans excheling drama and poetry. I would agree lhat drama has common denominators with the: abovenentioned catcgories, but strangely cuough Alrikanas poetry, with exceptions, on the whole does not lit into the system to which the novel belongs, especially with reference to theme. The explanation for this conld le that Alikatus peretry throughout its existence up to now has had a rendency to move away from regionalism to universalism - though, once again lhere are (exceptions.)

Arikaans poetry ean compete on grounds of literary value with poetry of many ofher literatures. Poetry of quality like the verses of Breyten Breyl(enbach, N.P. van Wyk J.ouw and D).J. (Opperman will transecend its lime.

In conclusion one may well ask whether there is not another kind of prose of literary value in Afrikanas, away from the political scenc and theme. ()ne must take into account that the Alrikaans-speaking population is relatively small and a small population can only produce a snall literary corpus in which the social novel lakes a dominant position.

In gencral many "lamous" modern novels in Afrikaans, due to the pressure of the times, belong to the realm of sociology and for that matter in a way to social realism - they are that, and therefore cannol be "real components of world literary poocess" (19833: 1.58).

The focus of literary criticism and literary evaluation tends to follow the linesof the novels thus engaged, result ing in a genesal viewpromt directed at this kind of literature not necessarily literary but very moch socially orientated. 'Thus evaluation is ofien based on the extemal relationship) of a 
work, wihout laking into accomm the intrinsir values. This is to the cleniment ol the developenent of a novel which comble well be regateded as belonging to the so-called "high literature". Jirom this point of view I hater, perforce, to come to the conclusion that the truly great novel in Afrikatus still has to lx written.

\section{BIBLIOGRAPHY}

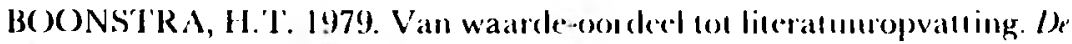
(iids 142 : 4, p. $243-252$.

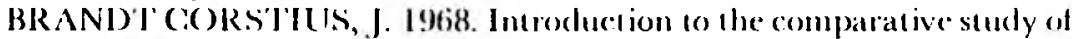
literature. New York: Randon House.

BRINK, A.P. 1983. Mapmakers - Writing in a state of sicge. 1 condon BusIon: Faber \& laber.

BIIllR, P. (red.) ? Verzen van verzel - Over de rol van de literatum in oul wikkelingslanden. Groningen R.U. : Bureau Buitenland.

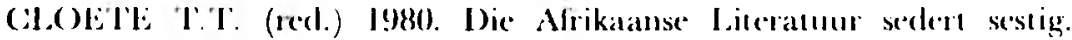
Katapstad: Nasou.

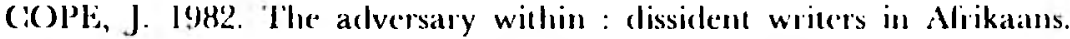
Kadpstad/London : l avid Philip / Hmmanities Press.

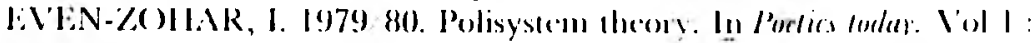
$\mathrm{I}-2,287-3 \mathrm{I})$.

FEINBER(i, B. (red.) 1974. Poets to the Pcople. London : George Allan \& luwin I, Id.

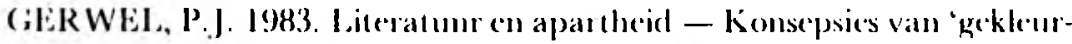
des' in dic Alrikatanse roman lot 1948. Kasselsstei : Kampentulgewers. (iR AY', S. (red.) 1976. A world of their own. Johannesburg : Ad I)onkere. IHERNSIIEIN-SMIIIt, Barbara. 1983: Contingencies ol Value. In Ciritual Imquior, Sipul. I'ol. 10, na. I.

HIRSCH, li.J) 1976. Ihe aims of interprelation. Chicago london: Iniversity of Chicago Press.

JÓZSEF, F. I 98.3. \%, Fragen der Elluk und Revulotion in der nenereni Ingarischen I.iteralur. Acla Lilleraria V'ol. $25 \mathrm{~N}$ I-2. p). 156-160.

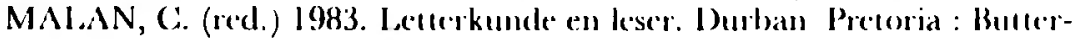
worth.

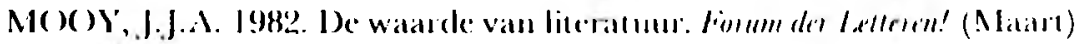
p. $18-3(1)$.

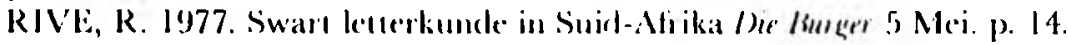

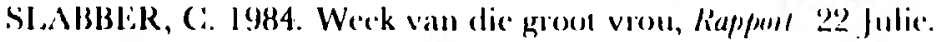

WIISSON F. (red.) 1984. Afican l.itcrature. Soulh fleican Oullook Vol. I I4(nr. I3.55) Mei. 